\title{
Article
}

\section{BIM-Based Research Framework for Sustainable Building Projects: A Strategy for Mitigating BIM Implementation Barriers}

\author{
Bilal Manzoor ${ }^{1}$, Idris Othman ${ }^{1}\left(\mathbb{D}\right.$, Syed Shujaa Safdar Gardezi ${ }^{2}$, Haşim Altan ${ }^{3, *(\mathbb{D}}$ and Salem \\ Buhashima Abdalla 4 (D) \\ 1 Department of Civil \& Environmental Engineering, University Technology PETRONAS (UTP), \\ Seri Iskandar 32610, Perak, Malaysia; bilal_18003504@utp.edu.my (B.M.); idris_othman@utp.edu.my (I.O.) \\ 2 Department of Civil Engineering, Capital University of Science and Technology (CUST), \\ Islamabad 44000, Pakistan; dr.shujaasafdar@cust.edu.pk \\ 3 Department of Architecture, Faculty of Design, Arkin University of Creative Art and Design (ARUCAD), \\ Kyrenia 99300, Cyprus \\ 4 Department of Architectural Engineering, College of Engineering, University of Sharjah (UOS), \\ Sharjah 27272, United Arab Emirates; sabdalla@sharjah.ac.ae \\ * Correspondence: hasim.altan@arucad.edu.tr
}

check for updates

Citation: Manzoor, B.; Othman, I.; Gardezi, S.S.S.; Altan, H.; Abdalla, S.B. BIM-Based Research Framework for Sustainable Building Projects: A Strategy for Mitigating BIM Implementation Barriers. Appl. Sci. 2021, 11, 5397. https://doi.org/ 10.3390/app11125397

Academic Editors: Lavinia Chiara Tagliabue and Ibrahim Yitmen

Received: 19 May 2021

Accepted: 8 June 2021

Published: 10 June 2021

Publisher's Note: MDPI stays neutral with regard to jurisdictional claims in published maps and institutional affiliations.

Copyright: (c) 2021 by the authors. Licensee MDPI, Basel, Switzerland. This article is an open access article distributed under the terms and conditions of the Creative Commons Attribution (CC BY) license (https:// creativecommons.org/licenses/by/ $4.0 /)$.

\begin{abstract}
Although Building Information Modeling (BIM) can enhance efficiency of sustainable building projects, its adoption is still plagued with barriers. In order to incorporate BIM more efficiently, it is important to consider and mitigate these barriers. The aim of this study is to explore and develop strategies to alleviate barriers in developing countries, such as Malaysia, to broaden implementation of BIM with the aid of quantitative and qualitative approaches. To achieve this aim, a comprehensive literature review was carried out to identify the barriers, and a questionnaire survey was conducted with construction projects' stakeholders. The ranking analysis results revealed the top five critical barriers to be "unavailability of standards and guidelines", "lack of BIM training", "lack of expertise", "high cost", and "lack of research and BIM implementation". Comparative study findings showed that "lack of research and BIM implementation" is the least important barrier in other countries like China, United Kingdom, Nigeria, and Pakistan. Furthermore, qualitative analysis revealed the strategies to mitigate the BIM implementation barriers to enhance sustainable goals. The final outcome of this study is the establishment of a framework incorporated with BIM implementation barriers and strategies namely, the "BIM-based research framework", which can assist project managers and policymakers towards effective sustainable construction.
\end{abstract}

Keywords: building information modeling; sustainable building; construction projects; BIM implementation; stakeholders; barriers

\section{Introduction}

With the rapid growth of the construction industry, an increasing number of sustainable building projects are underway all over the world and have far-reaching consequences for national and regional economic development [1]. All other industries rely to some extent on the construction industry because of their high productivity flow through the economy [2]. Similarly, Malaysia's construction industry, like other developing countries, varies from cost, time constraints, and efficiency, resulting in delays [3]. Moreover, due to budget and schedule overrun, most sustainable building projects struggle to achieve their goals. It is therefore important to use advanced digital technologies such as BIM in order to achieve the desired results effectively [4]. Using BIM in sustainable building projects has various advantages, such as reducing errors, rework, and waste [5-7]. In addition, the use of BIM in sustainable building projects facilitates multidisciplinary cooperation between different project teams, achieves the project objective, and increases the productivity of construction activities [8-10]. BIM can be used in any phase of sustainable 
building projects, such as visualization, cash detection, code checking, communication, collaboration, monitoring, time and cost management [11,12]. BIM also has the potential as a significant technical advancement in traditional CAD, offering more information and interoperability capabilities [13]. BIM has the power to transform the construction industry and is therefore considered to be the future of the construction industry [14].

Since buildings are of high economic value and have a major effect on the environment and quality of life, the construction industry can be considered one of the key elements for society's long-term growth [15]. Buildings are deemed sustainable if their environmental, economic, and social effects on the community have been properly addressed and have contributed to society's long-term growth [16]. In the past, it was anticipated that sustainable buildings would initially cost around $15 \%$ more than conventional ones [17].

In addition, it has been found that few studies have been conducted on barriers to the implementation of BIM in sustainable building projects. Memon et al. [4] used a survey of sample size questionnaires $(n=95)$ to report the barriers and found that BIM adoption in Malaysian construction was very low. However, the current analysis expands the scale of the study by increasing the number of survey respondents $(n=185)$. In addition, Zahrizan et al. [18] used the quantitative analysis approach through questionnaire surveys to identify barriers and to report that the lack of BIM awareness is a crucial barrier to the implementation of BIM. Subsequently, Hamid et al. [19] performed a report on barriers but limited to establishing only nine barriers. Wong et al. [20] conducted a recent study that emphasized the importance of transitioning from outdated approaches to sophisticated methodologies such as BIM in order to merge design and construction workflows with the goal of enhancing productivity. Therefore, strategies are needed to make the project successful and help construction stakeholders to perform effectively in order to achieve the sustainable goals.

Hence, this research aims to provide strategies for alleviating barriers with the approach of qualitative analysis and a BIM-based research framework for sustainable building projects. To fulfill the aim of the study, there were four research objectives as follows: (a) to identify barriers from the literature, (b) to rank the barriers with the aid of quantitative approach, (c) to provide strategies in order to mitigate the barriers with the aid of qualitative approach, and (d) to establish a BIM-based research framework integrating barriers and strategies for sustainable building projects. The intent of the research was to explore and uncover new knowledge gaps and practical needs of a BIM-based research framework for sustainable building projects. It would also serve as a theoretical foundation for adopting BIM in sustainable building projects.

The remainder of the paper is arranged in the following way: Section 2 addresses the theoretical background and research gaps. Section 3 explains the related works. Section 4 sets out the research methodology. Subsequently, Section 5 elaborates on the results and discussion. Section 6 explains the comparison of outcomes with other countries. Section 7 introduces the BIM-based research framework and is followed by Section 8, the conclusion, limitations, and future directions.

\section{Theoretical Background and Research Gaps}

BIM is defined as "a model of building information that provides full and necessary information to support all life-cycle processes and that can be directly interpreted by computer applications. It includes information on the building itself and its components, and involves information on the properties of the building, such as its structure, shape, material and life-cycle processes" [21]. The term "BIM" has several contradictory and misleading interpretations. Definitions may differ for different people in distinct organizations, depending on their point of views, work types, and functions. From a design perspective, for example, BIM is described as the digital representation of a project's physical and functional qualities, which relates to the methodology and technologies required to generate a model [22]. In the construction industry, BIM is defined as the creation and application of a computer software model to simulate the construction and operation of a facility [23]. 
The genesis, creation, and expansion of BIM ultimately represented the growth profile of computerization. In the late 1950s, Itek Corporation, a U.S. defense contractor, developed a computer graphics technology suitable for engineering design. This helped design visual representation technologies that had been integrated into commercial engineering design and design products. Subsequently, the idea was transformed into an Electronic Drafting Machine (EDM) [24]. By the mid-1960s, EDMs had been marketed for use by other organizations. During the 1970s and early 1980s, Applicon (founded in 1969 as Analytics, Inc. in Burlington, Massachusetts by a group of MIT Lincoln Laboratory programmers) provided 2D products for electrical design tasks. This included the concept of the printed circuit board and a 3D product named BRAVO! Computer Art and Design [24]. In the early 1980s, the BRAVO! The product has been considerably advanced. Since the early 1980s, Autodesk had been a significant competitor of Applicon and other CAD suppliers. Autodesk continues to be a pioneer in this area [25]. Distinctive characteristics such as structural analysis, monitoring and analysis of energy buildings, construction management, and performance tracking and even worker safety have recently been provided on AEC computer platforms [26]. The word BIM attracted $\mathrm{TM} /{ }^{\circledR} /{ }^{\complement}$, who began to promote it with their products [27]. In order to increase infrastructure development, reduce costs, and provide general management assistance during any step of construction, the BIM idea was introduced to the construction industry [28].

In the construction industry, barriers to BIM implementation are a challenge for stakeholders to improve sustainable goals. Almost the bulk of research in literature is related to the identification of barriers. For instance, BIM implementation barriers have been highlighted in Hong Kong but are not capable of providing strategies [29]. Similarly, a study was conducted in China and Australia to define, classify, and prioritize these barriers but not to establish strategies [30]. Researchers have recently performed barrierrelated research for promoting sustainable construction. For example, the barriers to strengthening team coordination in BIM-based construction networks and the construction of a conceptual model. This conceptual model offers an intermediate theory, that is, a theoretical basis for guiding further attempts at knowledge formation on the subject [8]. In addition, the advantages and barriers to the implementation of BIM have been applied with a quantitative approach but are not capable of having a strategy to overcome [31]. Therefore, to fill the aforementioned research gap, this study focuses on providing strategies in reducing the barriers for sustainable building projects with the aid of a BIM-based research framework.

\section{Related Work}

In this section, related works in the domain of barriers in the global and Malaysian context are discussed.

\subsection{BIM Implementation Barriers in Global Context}

Globally, fast growth demands and the overwhelming majority of construction companies have allocated BIM to improve the sustainability goals [32]. In sustainable building projects around the globe, the use of BIM has been advocated by government and professional bodies to provide more collaboration and cooperation between stakeholders in the construction sector and to ensure the quality of the projects [33]. Moreover, countries like the United Kingdom, the United States, Australia have adopted BIM in-depth research and other field areas like project management, facility management, and safety management $[34,35]$. In Australia and New Zealand, the implementation of BIM is only at level 2, with the main focus being on 2D and 3D collaboration [36]. The researchers revealed that "lack of faith in the integrity of BIM" and "lack of client demand" among other barriers were one of the factors behind the lack of BIM implementation in Australia [37]. Many researchers in Germany, the United Kingdom, Canada, the United States, Denmark, France, China, Brazil, South Korea, and the Middle East [38-46] have also found numerous BIM implementation barriers. It includes lack of BIM experience, investment costs, lack 
of awareness, lack of specified standards, market and cultural changes, interoperability problems, lack of specific guidelines for BIM implementation, and habitual resistance to change $[31,44,47]$. However, it has been found that the construction industry in the United States has engaged BIM in its ventures relative to other industries across the globe [48]. The government's BIM initiative became compulsory in projects in the public sector, beginning in 2016 in the UK [43]. It is therefore noticed that implementation of the BIM in different countries is growing for effective and productive construction [49]. However, there is a need to explore BIM in sustainable building projects for the sake of an eco-friendly environment and prompt sustainable goals.

\subsection{BIM Implementation Barriers in Malaysian Context}

In Malaysia, BIM implementation is still in the developing stage. However, the construction industry in Malaysia has taken major steps to encourage and boost construction efficiency at the national level with the introduction of BIM [50,51]. In addition, BIM is mandatory for public projects with a budget of RM 100 million or more from 2018 [52]. According to Datuk Seri Dr Roslan Md Taha (PWD Director-General), a total of 18 construction projects have been initiated by BIM in various construction phases up to 2017 such as SMK Meru Raya Ipoh Perak, Health Clinic Maran Pahang, MACC Selangor Shah Alam, UTHM Batu Pahat Johor and Parit Buntar Hospital [53]. With the continuous implementation of BIM against sustainable building projects in Malaysia, the implementation of BIM still faces numerous barriers and BIM implementation in sustainable building projects has many concerns and challenges. Hence, there is a need to better understand barriers in order to make the construction smoother and more effective for boosting sustainability goals. Various researchers have also highlighted the barriers to BIM implementation. The most critical barrier which was identified by many researchers is high cost [54-57]. Likewise, in Hong Kong and China, high cost is also considered as the BIM implementation barrier $[47,58]$. Moreover, it was also described as the topmost critical barrier in the Middle East [59]. As a result, high costs are included as one of the barriers since they are commonly available in the literature. In the last year, another study was conducted to explore the level of adoption of BIM in Malaysia. This study found that only $13 \%$ of government and private participants use BIM in their organization, which is negative evidence that Malaysia remains a long way from the role it should play in implementing BIM [60]. Therefore, it is recommended to implement BIM by eliminating barriers and providing the strategies for sustainable building projects.

\section{Research Methodology}

In this section, a brief explanation of the research methodology has been discussed. The research methodology section comprises data collection and data analysis. In addition, the research design flowchart, as shown in Figure 1, comprises four phases to fulfill the aim and objectives of this study. In the first step, the research aim and objectives were formulated by evaluating the relevant literature and identifying research gaps in previous research performed by researchers. The second phase of the study consists of collecting data from the literature review by defining the implementation barriers of the BIM and developing a questionnaire survey to be distributed among stakeholders (contractors, clients, and consultants). In the third step, the triangulation approach was introduced to achieve the study goal and the study objectives. The method of triangulation consists of two forms of analysis, i.e., quantitative analysis and qualitative analysis. According to Altricher et al. [61], triangulation "gives the more detailed and fair image of the circumstances". In quantitative analysis, the SPSS software package was used to assess the feedback of the respondents. The SPSS software was used to analyze the values of Cronbach's alpha coefficient, Kendall's coefficient of concordance (Kendall's W), Chi-square analysis, and mean score analysis, while NVivo software was used in qualitative analysis to analyze the data collected from interviews. In the final and fourth phase of the study, the recommendation and conclusion were drawn from the analysis results. 


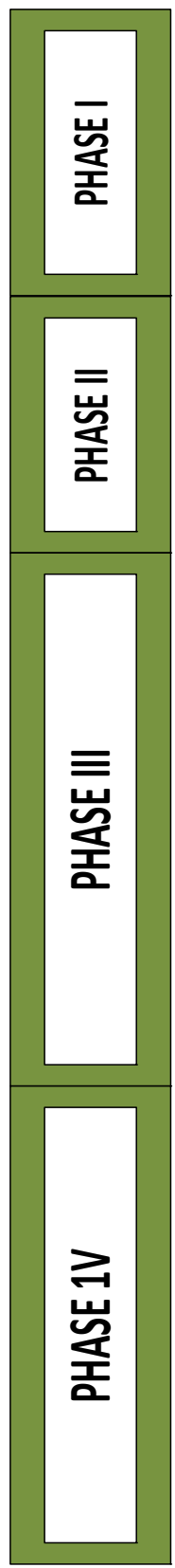

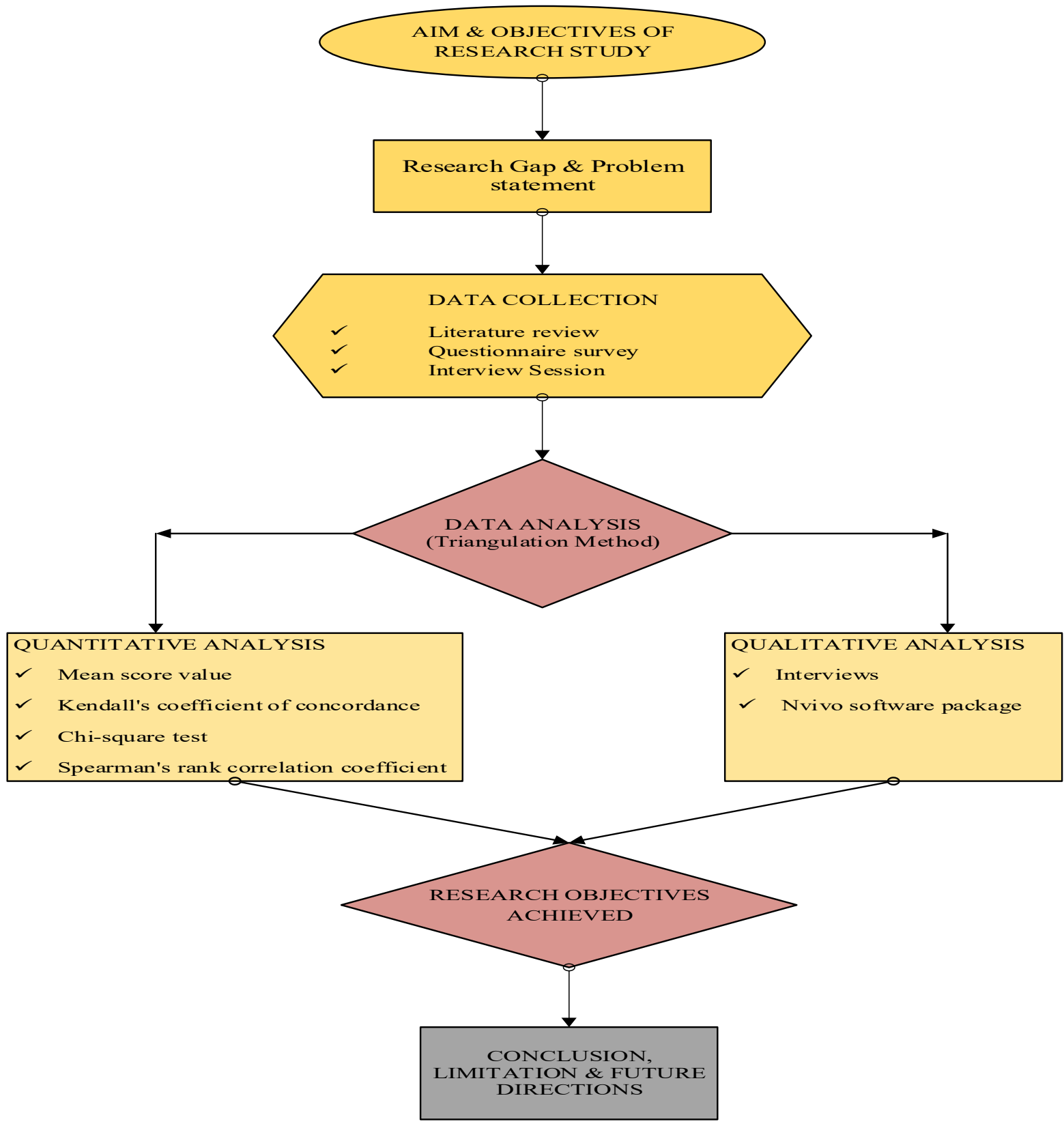

Figure 1. Research design flowchart.

\subsection{Data Collection}

After establishing the aim and objectives of the study in the introduction section, phase 2 of the study was conducted, which consisted of literature review, questionnaire survey, and interview session.

\subsubsection{Literature Search Parameters}

The purpose of the literature review was to identify barriers with various databases, such as Scopus, Web of Science, Google Scholar, and other relevant publications such as Elsevier, American Society of Civil Engineers (ASCE), Emerald and Taylor and Francis. Keywords such as "building information modeling", "construction industry", "construction projects", and "barriers" were used. Subsequently, the listed publications were screened, primarily by concentrating on the title, abstract, and conclusions, as well as the figures and 
tables. Table 1 elaborates the BIM implementation barriers that were used in this research study based on the existing literature.

Table 1. Building information modeling (BIM) implementation barriers.

\begin{tabular}{cc}
\hline BIM Implementation Barriers & References \\
High cost & {$[54-57]$} \\
Lack of expertise & {$[58,62-64]$} \\
Inadequate government policies & {$[47,65,66]$} \\
Lack of clients demand & {$[62,67]$} \\
Poor collaboration among stakeholders & {$[56,68,69]$} \\
Lack of vision of benefits & {$[4,38,70]$} \\
Unavailability of standards and guidelines & {$[18,58,71-73]$} \\
Lack of BIM training & {$[44,74,75]$} \\
Lack of promotion & {$[76-78]$} \\
Lack of initiative and hesitance & {$[79-81]$} \\
Lack of industry standards & {$[71,82,83]$} \\
Competing initiatives & {$[84-86]$} \\
Incompatibility and interoperability problems & {$[77,87,88]$} \\
Lack of well-developed practical strategies & {$[30,82,89-91]$} \\
Licensing issues & {$[82,92-94]$} \\
Security issues & {$[95-98]$} \\
Misunderstanding of BIM & {$[99-102]$} \\
Lack of research and BIM implementation & {$[60,103,104]$} \\
Cultural barrier (resistance to change) & {$[63,105-107]$} \\
\hline
\end{tabular}

After rigorous review of current literature relating to BIM implementation barriers, various factors were identified. Table 1 elaborates a list of 20 factors that are well documented and hence more applicable. Prior to identification of BIM implementation barriers, it is kept in mind that the selection of well-known factors is more reliable and also easy for the respondents to understand the theme and feedback easily.

Previous studies were used to identify the aforementioned BIM implementation barriers. Following a thorough evaluation of these studies, this study identified 20 potential barriers to BIM implementation, which are presented in Table 1. For example, cost, lack of expertise, and lack of promotion are commonly acknowledged in the literature as crucial barriers to BIM implementation.

\subsubsection{Questionnaire Survey}

In this section, questionnaire design and responses were examined. The questionnaire survey method was used to collect the data through a quantitative approach. Therefore, the questionnaire was designed after careful consideration of existing literature in the domain of BIM implementation barriers. Prior to the final questionnaire survey, a semi-structured interview was arranged to ensure the potential and appropriateness of the questionnaire in the context of BIM implementation barriers. In the pilot study, the feedback from five participants was used to further improve the questions prior to the actual questionnaire survey. The pilot survey consisted of two professors, two assistant professors, and one postgraduate researcher. The questionnaire was finalized based on feedback from the pilot study. The final questionnaire consists of three parts: (a) research aim and objectives, (b) general information of respondents, (c) rank of the barriers using a Likert scale (1-Strongly Disagree, 2-Disagree, 3-Moderately Agree, 4-Agree, 5-Strongly Agree). A total of 300 questionnaires were sent via email, and 185 feedbacks were received, yielding a response rate of $61 \%$. In addition, the sample size greater than 30 is reliable for further statistical analysis based on central limit theorem $[108,109]$. Figure 2 elaborates the breakdown of 185 returned questionnaires consisting of positions, working experience, education, and company type. 


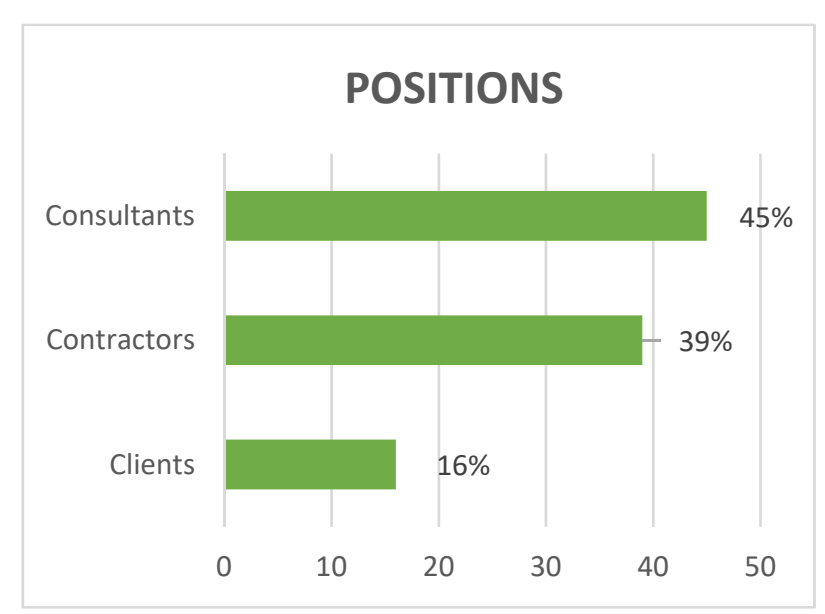

(a)

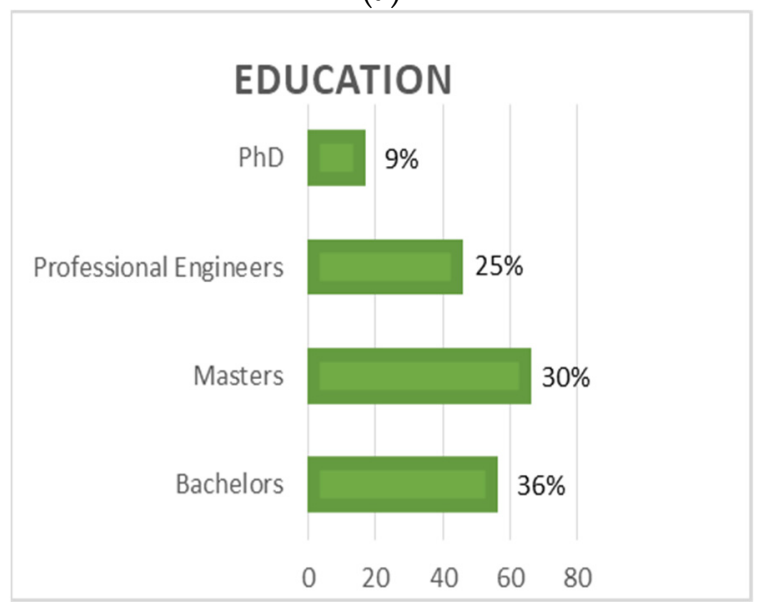

(c)

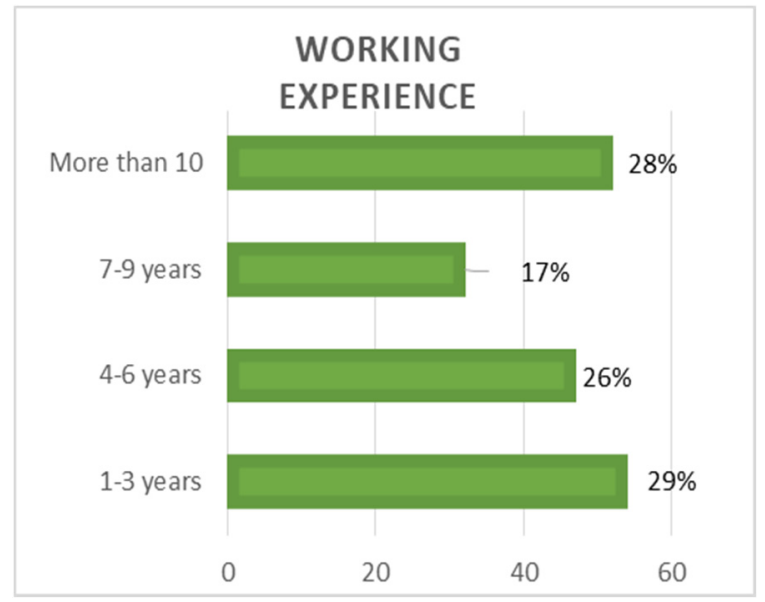

(b)

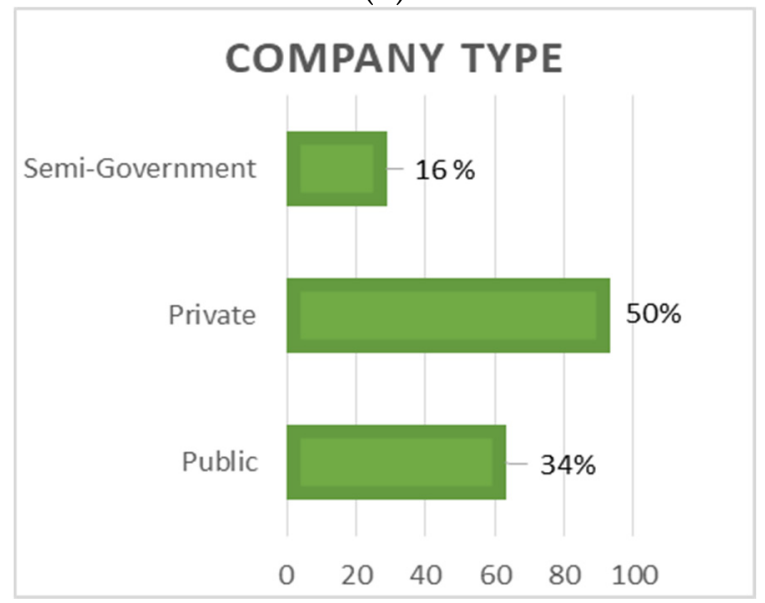

(d)

Figure 2. Breakdown of 185 returned questionnaires by Positions, Working Experience, Education, and Company Type (a-d).

Figure 2 depicts the positions of respondents, which include consultants, contractors, and clients. Consultants accounted for $45 \%$ of the total, contractors accounted for $39 \%$, and clients accounted for $16 \%$. Furthermore, $28 \%$ had more than ten years of work experience. Similarly, 36\% of respondents were Bachelor's degree holders, 30\% of respondents were Master's degree holders, $25 \%$ of respondents were professional engineers, and $9 \%$ of respondents were PhD holders. Furthermore, 16\% of respondents worked for a semigovernment organization, $50 \%$ of respondents worked for a private organization and $34 \%$ of respondents worked for a public organization.

\subsubsection{Interview Session}

In this section, interview questions design and responses were examined. The method of interviewing was used to gather data using a qualitative approach.

Due to the covid-19 pandemic, the online interviews were conducted using ZOOM software. Prior to conducting an online interview with ZOOM software, a semi-structured interview was created to ensure that all information related to barriers in construction projects could be obtained. In addition, previous studies have shown that the sample size greater than fifteen is effective and accurate for qualitative analysis [110]. The sample size of twenty for this qualitative analysis was therefore deemed to be appropriate. Twenty BIM experts with experience working in academia, industry, and construction projects were selected as participants in this qualitative analysis. Before the interview started, participants received a short introduction to the study and were informed of the anonymity and confidentiality of the information collected. Before the interviews started, demographic information such as gender, educational qualifications, and job experience was collected 
from interviewees. Interviewees were interviewed on the basis of the intended interview questions and after each answer, additional follow-up questions were asked as needed. The criteria for selection of participants depends upon: (a) possess working experience more than five years, (b) having excellent educational qualifications, (c) possess strong knowledge of BIM in construction projects. The demographic detail of participants is shown in Table 2.

Table 2. Participant demographics $(n=20)$.

\begin{tabular}{cccc}
\hline Item & Description & Number of Participants & Percentage (\%) \\
\hline \multirow{2}{*}{ Gender } & Male & 20 & 100 \\
& Female & - & - \\
\hline \multirow{2}{*}{ Educational } & Bachelors & 3 & 15 \\
qualification & Masters & 5 & 25 \\
& PhD & 6 & 30 \\
& Professional & 6 & 30 \\
& Engineers & 4 & 20 \\
Working experience & 5-7 years & 9 & 45 \\
& 8-9 years & 7 & 35 \\
\hline
\end{tabular}

It was seen that $100 \%$ of the participants were male, while none were female. Similarly, $15 \%$ of the participants were Bachelor's degree holders, while 25\%, 30\%, and 30\% of the participants were Master's degree holders, PhD holders, and professional engineers, respectively. In addition, 35\% of the participants had career experience of more than 10 years. The demographic analysis indicates that they had broad working experience, qualifications, and skills. Thus, they were considered as suitable interviewees for this research study.

\subsection{Data Analysis}

The third stage of study was data analysis. For this purpose, two types of data analysis were elaborated: (a) qualitative analysis via questionnaire survey and (b) qualitative analysis via interview.

\subsubsection{Quantitative Analysis}

Cronbach's alpha coefficient is used to calculate the internal consistency of the different variables in order to determine the strength of the five-point scales. The value for Cronbach's alpha coefficient in this study is 0.876 , which is greater than the threshold of 0.7, which suggests that the data are reliable for further statistical analysis [111]. Furthermore, the mean value technique is used to determine the relative importance of individual barriers. The mean values of individual barriers are computed, ranked, and compared between the three groups (contractors, consultants, clients). Mean value analysis is a technique used to effectively identify key factors among various factors [112]. In addition, Kendall's coefficient of concordance (Kendall's W) is also calculated to measure the agreement of responses in particular groups [113]. The range of the value of Kendall's coefficient of concordance $(\mathrm{W})$ is from 0 to 1 . The higher value of $\mathrm{W}$ indicates the high level of consensus among the respondents within the group [114,115]. In addition, chi-square analysis should be carried out, if the number of items is greater than seven [116]. In addition, the Spearman's rank correlation coefficient was introduced to calculate the strength of a relationship between two groups [117]. The range of the Spearman's rank correlation coefficient $\left(r_{s}\right)$ is from -1 to +1 . The higher the positive/negative value of $r_{s}$, the stronger positive/negative linear correlation [90]. 


\subsubsection{Qualitative Analysis}

For analysis of the qualitative study, NVivo 11 was used as one of the available software packages [118]. Using software packages such as NVivo improves the degree of deeper understanding and makes qualitative data analysis quicker and more flexible [119]. In qualitative analysis, coding is considered to be an integrated part of the analysis. The theme of the interview is further summarized through coding for a better analysis of the idea put forward by the participants. The ideas of the interviewees were further listed in 200 codes for qualitative analysis. For instance, the "government must establish a BIM cell unit and allocate a defined budget for BIM implementation." This theme and concept were broken down into "government policies". The details of the coding theme are shown in Table 3.

Table 3. Coding theme and appropriate definition.

\begin{tabular}{llll}
\hline \multicolumn{1}{c}{ Categories $(\boldsymbol{n}=\mathbf{2 0 0})$} & \multicolumn{1}{c}{ Subcategories } & Definition \\
\hline Development BIM guidelines (49) & $\bullet$ & $\begin{array}{l}\text { Positive attitude } \\
\text { Appropriate learning environment }\end{array}$ & Favor in developing BIM guidelines. \\
\hline Enhance BIM seminars/course/workshops (27) & $\bullet$ & $\begin{array}{l}\text { Compulsion } \\
\text { Appreciation } \\
\text { Professional bodies }\end{array}$ & Made compulsion to adopt BIM seminars. \\
\hline Hiring BIM experts (26) & $\bullet$ & $\begin{array}{l}\text { Awareness } \\
\text { Understanding }\end{array}$ & $\begin{array}{l}\text { To develop the know-how of BIM implementation, hire } \\
\text { BIM experts. }\end{array}$ \\
\hline Budget allocation (44) & $\bullet$ & Government policies & $\begin{array}{l}\text { Government should enhance the budget allocation to } \\
\text { BIM organizations and establish BIM cell. }\end{array}$ \\
\hline BIM and academic curriculum (54) & $\bullet$ & Collaboration & $\begin{array}{l}\text { To overcome the lack of research, adopt more } \\
\text { collaboration and exchange idea with different countries. }\end{array}$ \\
\hline
\end{tabular}

It was shown that interviewees emphasized the enhancement of BIM integrated with academic curricula to overcome the lack of BIM research and implementation. Likewise, a positive attitude and learning environment together with the creation of BIM guidelines are essential for grooming BIM implementation. Furthermore, interviewees suggested that the professional bodies should conduct BIM workshops, courses, and seminars to convey the benefits of using BIM in construction projects. Stakeholders should take part in workshops, seminars, and courses to grow the concept of incorporating BIM in their construction projects. Moreover, interviewees facilitated the development of know-how of BIM implementation, the dissemination of BIM information, and the development of awareness and understanding. Interviewees indicated that the government should assign the budget to BIM and set up a separate BIM-based allocation cell to track the proper use of the allocation budget. However, cooperation with other universities and countries is necessary in order to address the lack of study in the implementation of BIM and in organizations.

\section{Results and Discussion}

The follow-up section explores in detail the results of SPSS statistical package, which consists of mean value analysis, Kendall's coefficient of concordance (Kendall's W), chisquare test, and Spearman's rank correlation coefficient, and are summarized in the form of ranking.

\subsection{Ranking of BIM Implementation Barriers}

The ranking of BIM implementation barriers is categorized into four parts with the data analysis results using mean value: (a) overall ranking of BIM implementation barriers, (b) ranking according to contractors' perspectives, (c) ranking according to consultants' perspectives, and (d) ranking according to clients' perspectives. Table 4 illustrates the detailed picture of mean value analysis. 
Table 4. Ranking of BIM implementation barriers.

\begin{tabular}{|c|c|c|c|c|c|c|c|c|}
\hline \multirow{2}{*}{ BIM Implementation Barriers } & \multicolumn{2}{|c|}{$\begin{array}{c}\text { Overall } \\
\text { Respondents }\end{array}$} & \multicolumn{2}{|c|}{$\begin{array}{l}\text { Contractors' } \\
\text { Perspectives }\end{array}$} & \multicolumn{2}{|c|}{$\begin{array}{l}\text { Consultants' } \\
\text { Perspectives }\end{array}$} & \multicolumn{2}{|c|}{$\begin{array}{c}\text { Clients' } \\
\text { Perspectives }\end{array}$} \\
\hline & Mean Value & Rank & Mean Value & Rank & Mean Value & Rank & Mean Value & Rank \\
\hline $\begin{array}{l}\text { Unavailability of standards and } \\
\text { guidelines }\end{array}$ & 4.89 & 1 & 4.02 & 4 & 3.85 & 5 & 4.27 & 5 \\
\hline $\begin{array}{l}\text { Lack of BIM training } \\
\text { Lack of expertise }\end{array}$ & $\begin{array}{l}4.78 \\
4.52 \\
4.45\end{array}$ & $\begin{array}{l}2 \\
3 \\
4\end{array}$ & $\begin{array}{l}3.89 \\
4.65 \\
4.54\end{array}$ & $\begin{array}{l}5 \\
1 \\
2\end{array}$ & $\begin{array}{l}4.00 \\
4.32 \\
4.10\end{array}$ & $\begin{array}{l}4 \\
1 \\
3\end{array}$ & $\begin{array}{l}4.60 \\
4.71 \\
4.07\end{array}$ & $\begin{array}{l}3 \\
2 \\
6\end{array}$ \\
\hline $\begin{array}{l}\text { High cost } \\
\text { Lack of research and BIM }\end{array}$ & $\begin{array}{l}4.45 \\
4.03\end{array}$ & $\begin{array}{l}4 \\
5\end{array}$ & $\begin{array}{l}4.34 \\
4.21\end{array}$ & $\begin{array}{l}2 \\
3\end{array}$ & $\begin{array}{l}4.10 \\
3.41\end{array}$ & $\begin{array}{l}3 \\
7\end{array}$ & $\begin{array}{l}4.07 \\
4.83\end{array}$ & $\begin{array}{l}0 \\
1\end{array}$ \\
\hline $\begin{array}{l}\text { Cultural barrier (resistance to } \\
\text { change) }\end{array}$ & 3.89 & 6 & 3.61 & 7 & 4.22 & 2 & 4.42 & 4 \\
\hline Lack of promotion & 3.62 & 7 & 3.61 & 7 & 2.88 & 10 & 3.43 & 10 \\
\hline $\begin{array}{l}\text { Incompatibility and } \\
\text { interoperability problems }\end{array}$ & 3.43 & 8 & 3.02 & 11 & 2.88 & 10 & 3.23 & 11 \\
\hline $\begin{array}{l}\text { Insufficient external motivation } \\
\text { (insufficient customer and } \\
\text { market demands) }\end{array}$ & 3.22 & 9 & 3.44 & 9 & 2.65 & 12 & 3.23 & 11 \\
\hline $\begin{array}{l}\text { Lack of well-developed practical } \\
\text { strategies }\end{array}$ & 3.09 & 10 & 2.83 & 13 & 3.01 & 9 & 3.01 & 13 \\
\hline Security issues & 2.98 & 11 & 2.61 & 14 & 3.70 & 6 & 2.98 & 14 \\
\hline Lack of clients demand & 2.82 & 12 & 2.90 & 11 & 1.95 & 16 & 2.87 & 15 \\
\hline Lack of vision of benefits & 2.67 & 13 & 3.23 & 10 & 3.20 & 9 & 2.87 & 15 \\
\hline $\begin{array}{l}\text { Poor collaboration among } \\
\text { stakeholders }\end{array}$ & 2.44 & 14 & 3.73 & 6 & 2.21 & 15 & 3.88 & 7 \\
\hline Lack of initiative and hesitance & 2.32 & 15 & 2.01 & 17 & 2.42 & 13 & 3.88 & 7 \\
\hline Misunderstanding of BIM & 2.27 & 16 & 1.92 & 18 & 2.42 & 13 & 3.88 & 7 \\
\hline Inadequate government policies & 2.18 & 17 & 1.88 & 19 & 1.65 & 19 & 1.90 & 20 \\
\hline Licensing issues & 2.13 & 18 & 1.88 & 19 & 1.72 & 17 & 2.01 & 19 \\
\hline Lack of industry standards & 1.98 & 19 & 2.32 & 16 & 1.72 & 17 & 2.45 & 18 \\
\hline Competing initiatives & 1.92 & 20 & 2.43 & 15 & 1.54 & 20 & 2.61 & 17 \\
\hline
\end{tabular}

Table 4 indicates that "unavailability of standards and guidelines" had the highest mean value of $\mathrm{M}=4.89$, while "competing initiatives" had the lowest mean value of $\mathrm{M}=1.92$. Likewise, the top five barriers were "unavailability of standards and guidelines", with $\mathrm{M}=4.89$, "lack of BIM training", with $\mathrm{M}=4.78$, "lack of expertise" with $\mathrm{M}=4.52$, "high cost", with $\mathrm{M}=4.45$, and "lack of research and BIM implementation", with $\mathrm{M}=4.03$.

\subsection{Kendall's Coefficient of Concordance (Kendall's W)}

The value of Kendall's coefficient of concordance (Kendall's W) of overall respondents, contractors' perspectives, consultants' perspectives, and clients' perspectives were 0.183 , $0.175,0.169$, and 0.145 , respectively. The null hypothesis was rejected because all significance levels were 0.000 , which was less than the threshold level of $5 \%$. As a consequence, a substantial level was found among the respondents.

\subsection{Chi-Square Test}

The chi-square test was conducted as there were 20 factors in the analysis. The chisquare test should be performed if there are more than seven factors in the study, i.e., the chi-square test values for contactors' perspectives, consultants' perspectives, and clients' perspectives were $68,432,92,569$, and 123,324, respectively. According to the analytical findings, the groups of respondents had significant levels dependent on each other in each group.

\subsection{Spearman's Rank Correlation Coefficient}

Spearman's rank correlation coefficient $\left(r_{s}\right)$ is calculated by the following equation:

$$
r_{s}=1-\left[6 \sum_{n=1}^{5} \frac{\left(\mathrm{d}^{2}\right)}{n\left(n^{2}-1\right)}\right]
$$

where $r_{s}=$ Spearman's rank correlation coefficient; $\mathrm{d}=$ the difference between ranks assigned to items; $n=$ the number of respondents.

Using Spearman's rank correlation coefficient, the relationship between the perspective of clients, consultants, and contractors with the implementation barriers was shown. Spearman's rank correlation coefficients between all parties were established. The coef- 
ficient value between the consultant and contractor was 0.932 . The correlation between the client and consultant was 0.892 , whereas that between the client and contractor was 0.821 . In addition, there was also a significant relationship among the three parties, namely $0.000,0.000$, and 0.005 , respectively, which was smaller than the permissible amount of significance $(5 \%)$. In other words, it can be said that there was a strong correlation between consultant and contractor, client and consultant, and client and contractor.

\subsection{Results of Factor Analysis}

Factor analysis was carried out to further explore the barriers of BIM implementation in this study. The KMO value of this study was 0.512 , which is acceptable as it satisfies the threshold of 0.50 . Values below 0.50 should lead the researcher "to either collect more data or rethink which variables to include" [120]. These results are illustrated in Table 5. The detailed picture of factor analysis of barriers to BIM implementation in sustainable building projects was composed of five groups. These groups were Group 1-Government-related barriers, Group 2-Market-related barriers, Group 3-Personal-related barriers, Group 4-Construction environment-related barriers, and Group 5-Cost-risk barriers.

Table 5. Results of factor analysis (FA) on barriers to BIM implementation in sustainable building projects.

\begin{tabular}{|c|c|c|c|c|c|c|}
\hline Variables (Barriers) & 1 & 2 & 3 & 4 & 5 & Grouping \\
\hline Inadequate government policies & 0.987 & - & - & - & - & \multirow{5}{*}{ Government-related barriers } \\
\hline Unavailability of standards and guidelines & 0.820 & - & - & - & - & \\
\hline Lack of industry standards & 0.712 & - & - & - & - & \\
\hline Lack of well-developed practical strategies & 0.620 & - & - & - & - & \\
\hline Licensing issues & 0.567 & - & - & - & - & \\
\hline Lack of expertise & - & 0.834 & - & - & - & \multirow{5}{*}{ Market-related barriers } \\
\hline Lack of clients demand & - & 0.621 & - & - & - & \\
\hline Poor collaboration among stakeholders & - & 0.601 & - & - & - & \\
\hline Lack of promotion & - & 0.542 & - & - & - & \\
\hline $\begin{array}{l}\text { Insufficient external motivation (insufficient customer } \\
\text { and market demands) }\end{array}$ & - & 0.521 & - & - & - & \\
\hline Lack of vision of benefits & - & - & 0.821 & - & - & \multirow{4}{*}{ Personal-related barriers } \\
\hline Lack of BIM training & - & - & 0.743 & - & - & \\
\hline Misunderstanding of BIM & - & - & 0.612 & - & - & \\
\hline Cultural barrier (resistance to change) & - & - & 0.590 & - & - & \\
\hline Lack of initiative and hesitance & - & - & - & 0.798 & - & \multirow{4}{*}{$\begin{array}{c}\text { Construction } \\
\text { Environment-related barriers }\end{array}$} \\
\hline Incompatibility and interoperability problems & - & - & - & 0.656 & - & \\
\hline Competing initiatives & - & - & - & 0.532 & - & \\
\hline Lack of research and BIM implementation & - & - & - & 0.432 & - & \\
\hline High cost & - & - & - & - & 0.712 & \multirow{2}{*}{ Cost-risk barriers } \\
\hline Security issues & - & - & - & - & 0.677 & \\
\hline
\end{tabular}

\section{Results Comparison with Other Countries}

The findings of the current study were contrasted with other countries like China, the United Kingdom, Nigeria, and Pakistan. In addition, Table 6 elaborates the comparison of BIM implementation barriers with other countries.

By contrasting Malaysia's current study with China, "unavailability of standards and guidelines" was ranked first, while in Nigeria, "unavailability of standards and guidelines" was ranked fourth. However, "unavailability of standards and guidelines" could not gain the attention of researchers in the United Kingdom and in Pakistan and thus was marked as not identified. The "lack of BIM training" was not ranked in the top five in the United Kingdom, Nigeria, or Pakistan. However, "lack of BIM training" was labeled as not identified in China. Furthermore, "lack of expertise" was ranked third in the current study in Malaysia as well as in the United Kingdom. The "lack of expertise" in Nigeria was perceived to be the most crucial barrier. Moreover, "high cost" was ranked fourth in the current study in both Malaysia and China, while in Nigeria, "high cost" was ranked third. In addition, "lack of research and BIM implementation" was the least consideration barrier in the United Kingdom, Nigeria, and Pakistan.

These findings provide evidence that more attention needs to be paid to BIM research and implementation in Pakistan and that "lack of research and implementation of BIM" is a crucial barrier that is largely unidentified by researchers. It is also understandable 
that variations in ranks are due to different cultures and environmental factors in different countries. From this analysis, the conclusion can be drawn that barriers are similar among different countries but rank distinctively.

Table 6. Comparison of BIM implementation barriers.

\begin{tabular}{|c|c|c|c|c|c|}
\hline $\begin{array}{c}\text { Top Five } \\
\text { BIM Implementation Barriers }\end{array}$ & $\begin{array}{c}\text { Malaysia } \\
\text { (Current Study) }\end{array}$ & $\begin{array}{l}\text { China } \\
{[47]}\end{array}$ & $\begin{array}{c}\text { United Kingdom } \\
{[107]}\end{array}$ & $\underset{[74]}{\text { Nigeria }}$ & $\begin{array}{l}\text { Pakistan } \\
\text { [121] }\end{array}$ \\
\hline Unavailability of standards And guidelines & (Rank 1) & (Rank 1) & Not Identified & (Rank 4) & Not Identified \\
\hline Lack of BIM training & (Rank 2) & Not Identified & (Rank 7) & (Rank 15) & (Rank 12) \\
\hline Lack of expertise & (Rank 3) & (Rank 5) & (Rank 3) & (Rank 1) & (Rank 7) \\
\hline High cost & (Rank 4) & (Rank 4) & (Rank 3) & (Rank 11) & (Rank 9) \\
\hline Lack of research and BIM implementation & (Rank 5) & (Rank 7) & Not Identified & Not Identified & Not Identified \\
\hline
\end{tabular}

\section{BIM-Based Research Framework}

In this section, strategies to mitigate the BIM implementation barriers, namely "unavailability of standards and guidelines", "lack of BIM training", "lack of expertise", "high cost", and "lack of research and BIM implementation" were developed with the aid of the BIM-based research framework. This framework consists of two layers, namely the outer layer and the inner layer. The inner layer consists of barriers, while the outer layer, called the "mitigation layer", consists of strategies to overcome barriers.

The strategy to address the "unavailability of standards and guidelines" focused on the proper development of the BIM guidance plan and a positive attitude towards the learning environment. In developing countries, there is a lack of sound guidelines for sustainable building projects, which leads to cost overruns, delays, and waste. There is a need to establish a BIM guidance plan that can encourage and enhance the efficiency of sustainable construction, such as that in developing countries. It is important for owners to draw up a BIM execution plan during the pre-operation process. In addition, the strategy to reduce the "lack of BIM training" barrier is to strengthen BIM courses (linking with academia), seminars, and workshops. It is the liability of the professional bodies to control and track the essential eyes of construction stakeholders and organizations. Training should begin by educating workers on the relevance and usefulness of technology. Employee information on BIM technological innovation can be measured by a written analysis, such as an exit survey. These conclusions are based on responses such as "I think that recruiting skilled workers can be the best option", "I think that professional bodies should track construction organizations", and "I think that BIM courses, seminars and workshops should be made compulsory for stakeholders". In addition, the approach to reduce the "lack of expertise" barrier is to attract BIM experts and generate possible ideas for the appreciation of the use of BIM technology. Hiring BIM experts from developed countries will help to mitigate the barrier. In order to ensure that adequate technical support and expertise is available from the technology partner, construction companies can obtain all relevant information from the manufacturer before promising to incorporate and use the BIM technology. These conclusions are based on responses such as "I think the appropriate approach is to recruit BIM experts from developing countries", "I think the know-how to use BIM needs to be disseminated". Furthermore, a strategy to reduce the barrier of "high cost" is to assign a specific budget for a BIM implementation cell. The government should set up a BIM cell to increase the trust and enthusiasm of building stakeholders. It is the utmost duty of the BIM cell unit to adequately track and monitor the allocation budget and prepare the report by the end of each month. In order to enable construction stakeholders to use BIM technology, vendors should consider modifying their business models to reduce the initial costs of using these technologies. A subscriptionbased model or monthly payment plan over a fixed period may be a preferred model, as construction stakeholders may adjust periodic payments to match their usual billing cycle-shifting most upstream costs. However, daily payments should be reasonable. This is supported by responses such as "I think the government should allocate a budget for the implementation of BIM", "I think the government should adjust its policies", and "I think 
there should be a BIM cell unit". Furthermore, BIM-related topics have been included in the curriculum of civil and architectural engineering. Collaboration between universities and the promotion of a research culture will improve the implementation of the BIM. It is the government's duty to expand opportunities for students and faculty members through the development of scholarship programs, as indicated by responses such as "I think by cooperation", "I think fostering understanding of BIM technology", and "I think student exchange programs between universities in developing countries". In addition, a detailed picture of the BIM-based research framework is elaborated in Figure 3.

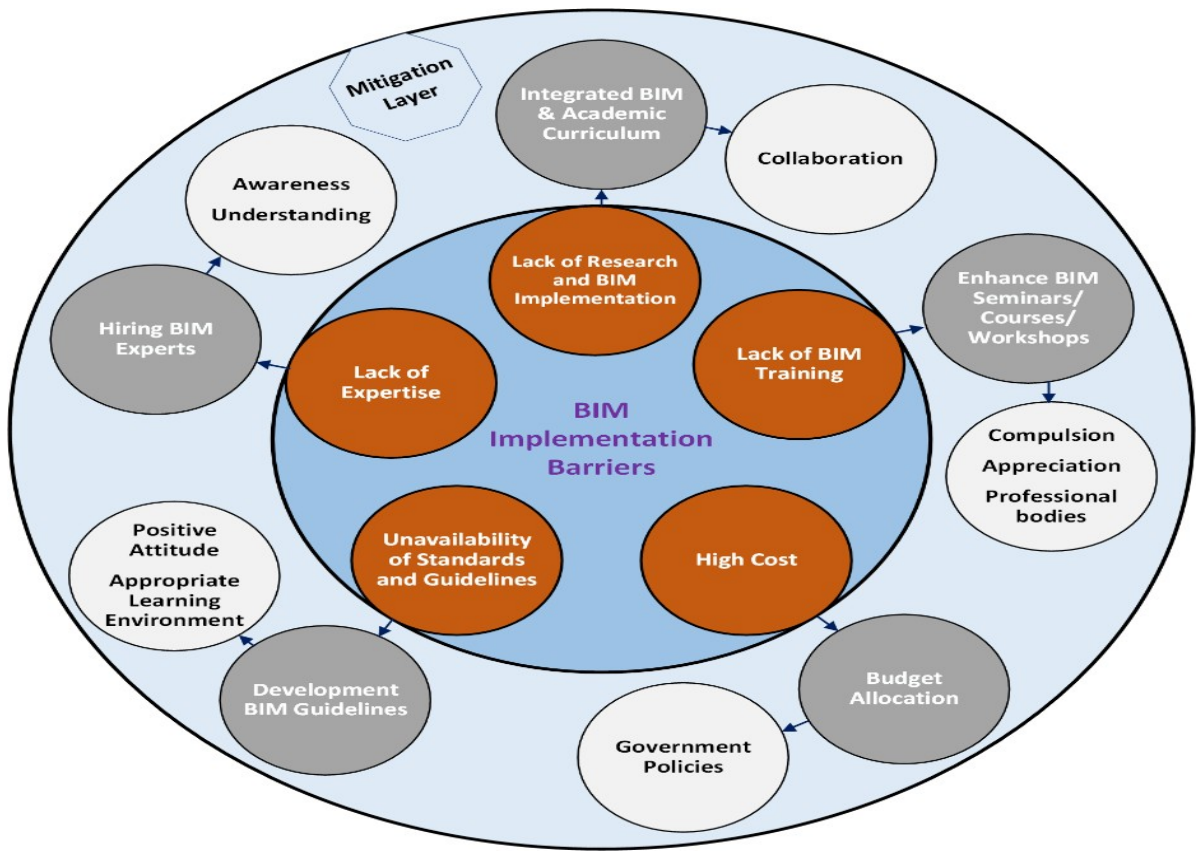

Figure 3. BIM-based research framework incorporating barriers and strategies for sustainable building projects.

\section{Conclusions, Limitation, and Future Directions}

BIM has the ability to enhance and ease construction, but there are various barriers that hinder the effectiveness of sustainable building projects. These barriers need to be tackled in order to boost successful and efficient construction. In addition, a comprehensive literature review was undertaken to illustrate the barriers in order to achieve the objectives of this study. Twenty barriers were established with a thorough analysis and proceeded to the questionnaire survey. In this study, the triangulation method consisting of quantitative analysis and qualitative analysis was adopted. In quantitative analysis, the top most barriers were "unavailability of standards and guidelines", with $\mathrm{M}=4.89$, "lack of BIM training", with $\mathrm{M}=4.78$, "lack of expertise", with $\mathrm{M}=4.52$, "high cost", with $\mathrm{M}=4.45$, and "lack of research and BIM implementation", with $\mathrm{M}=4.03$, whereas, "competing initiatives" had the lowest mean value of $M=1.92$. In qualitative analysis, strategies to mitigate barriers were explored with the help of interviews of BIM experts in academia and in sustainable building projects. It was revealed that BIM workshops, courses, and seminars could enhance and promote the culture of BIM implementation. In addition, collaboration and budget allocation could increase the incentive and trust level of research to address the lack of research and implementation of BIM.

The theoretical contribution of this study is not only to fill the research gap but also to provide a valuable reference for helping stakeholders to mitigate the barriers. As far as the authors' knowledge, the novelty of this study is that there is no comprehensive study conducted in Malaysia to explore strategies in mitigating BIM implementation barriers for sustainable building projects. For practical implications, this study suggests that the BIMbased research framework be executed with ongoing real projects to enable stakeholders to 
complete sustainable construction effectively. This study also recommends that researchers create slightly different frameworks on the basis of the same collection of quantitative and qualitative data. While the aim and objectives of this research were accomplished, this study still has some limitations that are worth noting. First, this study was conducted in Malaysia, and therefore the findings in this study might not be applicable in other countries because of cultural differences. Second, in the qualitative study, the sample size could be expanded in order to gain further insight into the reduction of BIM implementation barriers. Finally, these limitations offer a route for potential researchers to verify this research study through case studies of successful construction projects.

Author Contributions: B.M.: Conceptualization, investigation, data curation, writing-original draft. I.O.; supervision, writing-review and editing. S.S.S.G., H.A. and S.B.A.; resources, review and editing. All authors have read and agreed to the published version of the manuscript.

Funding: This research received no external funding.

Institutional Review Board Statement: Not applicable.

Informed Consent Statement: Not applicable.

Data Availability Statement: Data sharing not applicable.

Conflicts of Interest: The authors declare no conflict of interest.

\section{References}

1. Mok, K.Y.; Shen, G.Q.; Yang, J. Stakeholder management studies in mega construction projects: A review and future directions. Int. J. Proj. Manag. 2015, 33, 446-457. [CrossRef]

2. Chia, F.C.; Skitmore, M.; Runeson, G.; Bridge, A. Economic development and construction productivity in Malaysia. Constr. Manag. Econ. 2014, 32, 874-887. [CrossRef]

3. Rahman, I.A.; Memon, A.H.; Nagapan, S.; Latif, Q.B.A.I.; Azis, A.A.A. Time and cost performance of construction projects in southern and central regions of Peninsular Malaysia. In 2012 IEEE Colloquium on Humanities, Science and Engineering (CHUSER); IEEE: Peninsular, Malaysia, 2012; pp. 52-57.

4. Memon, A.H.; Rahman, I.A.; Memon, I.; Azman, N.I.A. BIM in Malaysian construction industry: Status, advantages, barriers and strategies to enhance the implementation level. Res. J. Appl. Sci. Eng. Technol. 2014, 8, 606-614. [CrossRef]

5. Cheng, J.C.P.; Won, J.; Das, M. Construction and demolition waste management using BIM technology. In Proceedings of the 23rd Annual Conference of the International Group for Lean Construction, Perth, Australia, 29-31 July 2015; pp. 381-390.

6. Hwang, B.-G.; Zhao, X.; Yang, K.W. Effect of BIM on rework in construction projects in Singapore: Status quo, magnitude, impact, and strategies. J. Constr. Eng. Manag. 2019, 145, 4018125. [CrossRef]

7. Ham, N.; Moon, S.; Kim, J.-H.; Kim, J.-J. Economic analysis of design errors in BIM-based high-rise construction projects: Case study of Haeundae L project. J. Constr. Eng. Manag. 2018, 144, 5018006. [CrossRef]

8. Oraee, M.; Hosseini, M.R.; Edwards, D.J.; Li, H.; Papadonikolaki, E.; Cao, D. Collaboration barriers in BIM-based construction networks: A conceptual model. Int. J. Proj. Manag. 2019, 37, 839-854. [CrossRef]

9. Oraee, M.; Hosseini, M.R.; Papadonikolaki, E.; Palliyaguru, R.; Arashpour, M. Collaboration in BIM-based construction networks: A bibliometric-qualitative literature review. Int. J. Proj. Manag. 2017, 35, 1288-1301. [CrossRef]

10. Doumbouya, L.; Gao, G.; Guan, C. Adoption of the Building Information Modeling (BIM) for construction project effectiveness: The review of BIM benefits. Am. J. Civ. Eng. Archit. 2016, 4, 74-79.

11. Latiffi, A.A.; Mohd, S.; Kasim, N.; Fathi, M.S. Building Information Modeling (BIM) Application in Malaysian Construction Industry. Int. J. Constr. Eng. Manag. 2013, 2, 1-6. [CrossRef]

12. Latiffi, A.A.; Brahim, J.; Fathi, M.S. Transformation of Malaysian construction industry with building information modelling (BIM). In MATEC Web of Conferences; EDP Sciences: Kuala Lumpur, Malaysia, 2016; p. 22.

13. Lee, G.; Sacks, R.; Eastman, C.M. Specifying parametric building object behavior (BOB) for a building information modeling system. Autom. Constr. 2006, 15, 758-776. [CrossRef]

14. Qureshi, A.H.; Alaloul, W.S.; Manzoor, B.; Musarat, M.A.; Saad, S.; Ammad, S. Implications of Machine Learning Integrated Technologies for Construction Progress Detection Under Industry 4.0 (IR 4.0). In Proceedings of the 2020 Second International Sustainability and Resilience Conference: Technology and Innovation in Building Designs, Sakheer, Bahrain, 11-12 November 2020.

15. Ortiz, O.; Castells, F.; Sonnemann, G. Sustainability in the construction industry: A review of recent developments based on LCA. Constr. Build. Mater. 2009, 23, 28-39. [CrossRef]

16. Lützkendorf, T.; Lorenz, D. Sustainable property investment: Valuing sustainable buildings through property performance assessment. Build. Res. Inf. 2005, 33, 212-234. [CrossRef] 
17. Hong, J.; Shen, G.Q.; Li, Z.; Zhang, B.; Zhang, W. Barriers to promoting prefabricated construction in China: A cost-Benefit analysis. J. Clean. Prod. 2018, 172, 649-660. [CrossRef]

18. Zahrizan, Z.; Ali, N.M.; Haron, A.T.; Marshall-Ponting, A.; Abd, Z. Exploring the adoption of Building Information Modelling (BIM) in the Malaysian construction industry: A qualitative approach. Int. J. Res. Eng. Technol. 2013, 2, 384-395.

19. Hamid, A.B.A.; Taib, M.Z.M.; Razak, A.H.N.A.; Embi, M.R. Building information modelling: Challenges and barriers in implement of BIM for interior design industry in Malaysia. In IOP Conference Series: Earth and Environmental Science; IOP Publishing: Langkawi Malaysia, 2018; p. 12002.

20. Wong, J.H.; Rashidi, A.; Arashpour, M. Evaluating the Impact of Building Information Modeling on the Labor Productivity of Construction Projects in Malaysia. Buildings 2020, 10, 66. [CrossRef]

21. van Nederveen, S.; Beheshti, R.; Gielingh, W. Modelling concepts for BIM. In Handbook of Research on Building Information Modeling and Construction Informatics: Concepts and Technologies; IGI Global: Delft, The Netherlands, 2010. [CrossRef]

22. Latiffi, A.A.; Brahim, J.; Fathi, M.S. The development of building information modeling (BIM) definition. In Applied Mechanics and Materials; Trans Tech Publications Ltd.: Nilai, Malaysia, 2014; pp. 625-630.

23. Heermann, D.W. Computer-simulation methods. In Computer Simulation Methods in Theoretical Physics; Springer: Berlin/Heidelberg, Germany, 1990; pp. 8-12. [CrossRef]

24. Weisberg, D.E. The engineering design revolution: The people, companies and computer systems that changed forever the practice of engineering. Cyon Res. Corp. 2008, 12, 1-26.

25. Becerik-Gerber, B.; Jazizadeh, F.; Li, N.; Calis, G. Application areas and data requirements for BIM-enabled facilities management. J. Constr. Eng. Manag. 2012, 138, 431-442. [CrossRef]

26. EGarcia, G.; Zhu, Z. Interoperability from building design to building energy modeling. J. Build. Eng. 2015, 1, 33-41.

27. Hannus, M. FIATECH Capital Projects Technology Roadmap, ECTP FA PICT. 2007. Available online: http//www.fiatech.org/ Tech-Roadmap (accessed on 25 May 2012).

28. Succar, B. Building information modelling framework: A research and delivery foundation for industry stakeholders. Autom. Constr. 2009, 18, 357-375. [CrossRef]

29. Chan, C.T.W. Barriers of implementing BIM in construction industry from the designers' perspective: A Hong Kong experience. J. Syst. Manag. Sci. 2014, 4, 24-40.

30. Liu, S.; Xie, B.; Tivendal, L.; Liu, C. Critical barriers to BIM implementation in the AEC industry. Int. J. Mark. Stud. 2015, 7, 162. [CrossRef]

31. Chan, D.W.M.; Olawumi, T.O.; Ho, A.M.L. Perceived benefits of and barriers to Building Information Modelling (BIM) implementation in construction: The case of Hong Kong. J. Build. Eng. 2019, 25, 100764. [CrossRef]

32. Olawumi, T.O.; Chan, D.W.M. Identifying and prioritizing the benefits of integrating BIM and sustainability practices in construction projects: A Delphi survey of international experts. Sustain. Cities Soc. 2018, 40, 16-27. [CrossRef]

33. Sepasgozar, S.M.E.; Hui, F.K.P.; Shirowzhan, S.; Foroozanfar, M.; Yang, L.; Aye, L. Lean Practices Using Building Information Modeling (BIM) and Digital Twinning for Sustainable Construction. Sustainability 2021, 13, 161. [CrossRef]

34. Olawumi, T.O.; Chan, D.W.M.; Wong, J.K.W. Evolution in the intellectual structure of BIM research: A bibliometric analysis. J. Civ. Eng. Manag. 2017, 23, 1060-1081. [CrossRef]

35. Wong, J.K.W.; Zhou, J. Enhancing environmental sustainability over building life cycles through green BIM: A review. Autom. Constr. 2015, 57, 156-165. [CrossRef]

36. von Both, P. Potentials and barriers for implementing BIM in the German AEC market: Results of a current market analysis. In Proceedings of the 30th eCAADe Conference, Prague, Czech Republic, 12-14 September 2012; pp. 151-158.

37. Aibinu, A.; Venkatesh, S. Status of BIM adoption and the BIM experience of cost consultants in Australia. J. Prof. Issues Eng. Educ. Pract. 2014, 140, 4013021. [CrossRef]

38. Arayici, Y.; Khosrowshahi, F.; Ponting, A.M.; Mihindu, S.A. Towards implementation of building information modelling in the construction industry. In Proceedings of the Fifth International Conference on Construction in the 21st Century: Collaboration and Integration in Engineering, Management and Technology, Istanbul, Turkey, 20-22 May 2009; pp. $1342-1351$.

39. Porwal, A.; Hewage, K.N. Building Information Modeling (BIM) partnering framework for public construction projects. Autom. Constr. 2013, 31, 204-214. [CrossRef]

40. Cao, Y.; Zhang, L.H.; McCabe, B.; Shahi, A. The Benefits of and Barriers to BIM Adoption in Canada. In Proceedings of the 36th International Association for Automation and Robotics in Construction (ISARC), Banff, AB, Canada, 21-24 May 2019 ; pp. 152-158.

41. Ku, K.; Taiebat, M. BIM experiences and expectations: The constructors' perspective. Int. J. Constr. Educ. Res. 2011, 7, 175-197. [CrossRef]

42. Jensen, P.A.; Jóhannesson, E.I. Building information modelling in Denmark and Iceland. Eng. Constr. Archit. Manag. 2013, 20, 99-110. [CrossRef]

43. Davies, R.; Crespin-Mazet, F.; Linne, A.; Pardo, C.; Havenvid, M.I.; Harty, C.; Ivory, C.; Salle, R. BIM in Europe: Innovation Networks in the Construction Sectors of Sweden France and the UK. In Proceedings of the 31st Annual ARCOM Conference, Lincoln, UK, 7-9 September 2015; pp. 1135-1144.

44. Tan, T.; Chen, K.; Xue, F.; Lu, W. Barriers to Building Information Modeling (BIM) implementation in China's prefabricated construction: An interpretive structural modeling (ISM) approach. J. Clean. Prod. 2019, 219, 949-959. [CrossRef] 
45. Obi, L.; Awuzie, B.; Obi, C.; Omotayo, T.S.; Oke, A.; Osobajo, O. BIM for Deconstruction: An Interpretive Structural Model of Factors Influencing Implementation. Buildings 2021, 11, 227. [CrossRef]

46. Al-Yami, A.; Sanni-Anibire, M.O. BIM in the Saudi Arabian construction industry: State of the art, benefit and barriers. Int. J. Build. Pathol. Adapt. 2019, 39, 33-47. [CrossRef]

47. Zhou, Y.; Yang, Y.; Yang, J.-B. Barriers to BIM implementation strategies in China. Eng. Constr. Archit. Manag. 2019, 26, 554-574. [CrossRef]

48. Yan, H.; Demian, P. Benefits and Barriers of Building Information Modelling. In Proceedings of the 12th International Conference on Computing in Civil Building Engineering (ICCCBE XII), Beijing, China, 16-18 Octoner 2008.

49. Volk, R.; Stengel, J.; Schultmann, F. Building Information Modeling (BIM) for existing buildings-Literature review and future needs. Autom. Constr. 2014, 38, 109-127. [CrossRef]

50. Musa, S.; Marshall-Ponting, A.; Nifa, F.A.A.; Shahron, S.A. Building information modeling (BIM) in Malaysian construction industry: Benefits and future challenges. In AIP Conference Proceedings; AIP Publishing LLC: Melville, NY, USA, 2018 ; p. 20105. [CrossRef]

51. Latiffi, A.A.; Mohd, S.; Brahim, J. Application of building information modeling (BIM) in the Malaysian construction industry: A story of the first government project. In Applied Mechanics and Materials; Trans Tech Publications Ltd.: Bäch, Switzerland, 2015; pp. 996-1001. [CrossRef]

52. Hasni, M.I.A.K.; Ismail, Z.; Hashim, N.; Hassan, A.A. A Review of Building Information Modelling (BIM) Documents in the Malaysian Construction Industry: Public Works Department (PWD) and Construction Industry Development Board (CIDB). Adv. Sci. Lett. 2018, 24, 8913-8916. [CrossRef]

53. CIDB Malaysia. Construction Industry Transformation Programme 2016-2020; CIDB: Kuala Lumpur, Malaysia, 2015.

54. Wong, A.K.D.; Wong, F.K.W.; Nadeem, A. Attributes of building information modelling and its development in Hong Kong. HKIE Trans. 2009, 16, 38-45. [CrossRef]

55. Hong, Y.; Hammad, A.; Zhong, X.; Wang, B.; Akbarnezhad, A. Comparative modeling approach to capture the differences in BIM adoption decision-making process in Australia and China. J. Constr. Eng. Manag. 2020, 146, 4019099. [CrossRef]

56. Won, J.; Lee, G. Identifying the consideration factors for successful BIM projects. In Proceedings of the 17th International Workshop on Intelligent Computing in Engineering (EG-ICE 2010), Nottingham, UK, 12-13 July 2019.

57. Czmoch, I.; Pękala, A. Traditional design versus BIM based design. Procedia Eng. 2014, 91, 210-215. [CrossRef]

58. Ma, X.; Darko, A.; Chan, A.P.C.; Wang, R.; Zhang, B. An empirical analysis of barriers to building information modelling (BIM) implementation in construction projects: evidence from the Chinese context. Int. J. Constr. Manag. 2020. [CrossRef]

59. Mehran, D. Exploring the Adoption of BIM in the UAE Construction Industry for AEC Firms. Procedia Eng. 2016, 145, 1110-1118. [CrossRef]

60. Othman, I.; Al-Ashmori, Y.Y.; Rahmawati, Y.; Amran, Y.H.M.; Al-Bared, M.A.M. The level of Building Information Modelling (BIM) Implementation in Malaysia. Ain Shams Eng. J. 2020, 12, 455-463. [CrossRef]

61. Altricher, H.; Feldman, A.; Posch, P.; Somekh, B. Teachers Investigate Their Work: An Introduction to Action Research across the Professions; Routledge: New York, NY, USA, 2005.

62. Wong, S.Y.; Gray, J. Barriers to implementing Building Information Modelling (BIM) in the Malaysian construction industry. In IOP Conference Series: Materials Science and Engineering; IOP Publishing: Bristol, UK, 2019.

63. Becerik-Gerber, B.; Kensek, K. Building information modeling in architecture, engineering, and construction: Emerging research directions and trends. J. Prof. Issues Eng. Educ. Pract. 2010, 136, 139-147. [CrossRef]

64. Kassem, M.; Brogden, T.; Dawood, N. BIM and 4D planning: A holistic study of the barriers and drivers to widespread adoption. J. Constr. Eng. Proj. Manag. 2012, 2, 1-10. [CrossRef]

65. Olanrewaju, O.I.; Chileshe, N.; Babarinde, S.A.; Sandanayake, M. Investigating the barriers to building information modeling (BIM) implementation within the Nigerian construction industry. Eng. Constr. Archit. Manag. 2020, 27, 2931-2958. [CrossRef]

66. Shafiq, M.T.; Afzal, M. Improving Construction Job Site Safety with Building Information Models: Opportunities and Barriers. In International Conference on Computing in Civil and Building Engineering; Springer: Cham, Switzerland, 2020; pp. 1014-1036.

67. Zahrizan, Z.; Ali, N.M.; Haron, A.T.; Marshall-Ponting, A.J.; Hamid, Z.A. Exploring the barriers and driving factors in implementing building information modelling (BIM) in the Malaysian construction industry: A preliminary study. J. Inst. Eng. Malays. 2014, $75,1-10$.

68. Harding, J.; Suresh, S.; Renukappa, S.; Mushatat, S. Do building information modelling applications benefit design teams in achieving BREEAM accreditation? J. Constr. Eng. 2014, 2014, 1-8. [CrossRef]

69. Hope, A.; Alwan, Z. Building the future: Integrating building information management and environmental assessment methodologies. In Proceedings of the First UK Academic Conference on BIM, Newcastle, UK, 5-7 September 2012.

70. Lee, S.-K.; Kim, K.-R.; Yu, J.-H. BIM and ontology-based approach for building cost estimation. Autom. Constr. 2014, 41, 96-105. [CrossRef]

71. Rogers, J.; Chong, H.-Y.; Preece, C. Adoption of building information modelling technology (BIM). Eng. Constr. Archit. Manag. 2015, 22, 424-445. [CrossRef]

72. Gerges, M.; Austin, S.; Mayouf, M.; Ahiakwo, O.; Jaeger, M.; Saad, A.; El Gohary, T. An investigation into the implementation of Building Information Modeling in the Middle East. J. Inf. Technol. Constr. 2017, 22, 1-15. 
73. Gu, N.; London, K. Understanding and facilitating BIM adoption in the AEC industry. Autom. Constr. 2010, 19, 988-999. [CrossRef]

74. Babatunde, S.O.; Udeaja, C.; Adekunle, A.O. Barriers to BIM implementation and ways forward to improve its adoption in the Nigerian AEC firms. Int. J. Build. Pathol. Adapt. 2020, 39, 48-71. [CrossRef]

75. Li, H.; Wang, Y.; Yan, H.; Deng, Y. Barriers of BIM application in China-Preliminary research. In ICCREM 2016 BIM Application and Off-Site Construction; American Society of Civil Engineers: Reston, VA, USA, 2017; pp. 37-41.

76. Ding, Z.; Zuo, J.; Wu, J.; Wang, J.Y. Key factors for the BIM adoption by architects: A China study. Eng. Constr. Archit. Manag. 2015, 22, 732-748. [CrossRef]

77. Jin, R.; Hancock, C.M.; Tang, L.; Wanatowski, D. BIM investment, returns, and risks in China's AEC industries. J. Constr. Eng. Manag. 2017, 143, 4017089. [CrossRef]

78. Matthews, J.; Love, P.E.D.; Mewburn, J.; Stobaus, C.; Ramanayaka, C. Building information modelling in construction: Insights from collaboration and change management perspectives. Prod. Plan. Control 2018, 29, 202-216. [CrossRef]

79. Bradley, A.; Li, H.; Lark, R.; Dunn, S. BIM for infrastructure: An overall review and constructor perspective. Autom. Constr. 2016, 71, 139-152. [CrossRef]

80. Bui, N.; Merschbrock, C.; Munkvold, B.E. A review of Building Information Modelling for construction in developing countries. Procedia Eng. 2016, 164, 487-494. [CrossRef]

81. Arayici, Y.; Coates, P.; Koskela, L.; Kagioglou, M.; Usher, C.; O’Reilly, K. Technology adoption in the BIM implementation for lean architectural practice. Autom. Constr. 2011, 20, 189-195. [CrossRef]

82. Azhar, S.; Khalfan, M.; Maqsood, T. Building information modelling (BIM): Now and beyond. Constr. Econ. Build. 2012, 12, 15-28. [CrossRef]

83. Matarneh, R.; Hamed, S. Barriers to the adoption of building information modeling in the Jordanian building industry. Open J. Civ. Eng. 2017, 7, 325-335. [CrossRef]

84. Abubakar, M.; Ibrahim, Y.M.; Kado, D.; Bala, K. Contractors' perception of the factors affecting Building Information Modelling (BIM) adoption in the Nigerian Construction Industry. In Proceedings of the Computing in Civil and Building Engineering, Orlando, FL, USA, 23-25 June 2014; pp. 167-178.

85. Akerele, A.O.; Etiene, M. Assessment of the level of awareness and limitations on the use of building information modeling in Lagos State. Int. J. Sci. Res. Publ. 2016, 6, 229-233.

86. SBabatunde, O.; Perera, S.; Ekundayo, D.; Adeleke, D.S. An investigation into BIM uptake among contracting firms: An empirical study in Nigeria. J. Financ. Manag. Prop. Constr. 2020, 26, 23-48. [CrossRef]

87. Bernstein, P.G.; Pittman, J.H. Barriers to the adoption of building information modeling in the building industry. Autodesk Build. Solut. 2004, 32, 1-14.

88. Gardezi, S.S.S.; Shafiq, N.; Nuruddin, M.F.; Farhan, S.A.; Umar, U.A. Challenges for implementation of building information modeling (BIM) in Malaysian construction industry. In Applied Mechanics and Materials; Trans Tech Publications Ltd.: Nilai, Malaysia, 2014; pp. 559-564.

89. Thompson, D.B.; Miner, R.G. Building Information Modeling-BIM: Contractual Risks Are Changing with Technology. 2006. Available online: http//www.aepronet.org/ge/no35.html (accessed on 20 April 2020).

90. Olawumi, T.O.; Chan, D.W.M.; Wong, J.K.W.; Chan, A.P.C. Barriers to the integration of BIM and sustainability practices in construction projects: A Delphi survey of international experts. J. Build. Eng. 2018, 20, 60-71. [CrossRef]

91. Ahmed, S. Barriers to implementation of building information modeling (BIM) to the construction industry: A review. J. Civ. Eng. Constr. 2018, 7, 107-113. [CrossRef]

92. Ahn, K.-U.; Kim, Y.-J.; Park, C.-S.; Kim, I.; Lee, K. BIM interface for full vs. semi-automated building energy simulation. Energy Build. 2014, 68, 671-678. [CrossRef]

93. Sardroud, J.M.; Mehdizadehtavasani, M.; Khorramabadi, A.; Ranjbardar, A. Barriers Analysis to Effective Implementation of BIM in the Construction Industry. In ISARC, Proceedings of the International Symposium on Automation and Robotics in Construction; IAARC Publications: Berlin, Germany, 2018; pp. 1-8.

94. Hamada, H.M.; Haron, A.; Zakiria, Z.; Humada, A.M. Benefits and barriers of BIM adoption in the Iraqi construction firms. Int. J. Innov. Res. Adv. Eng. 2016, 3, 76-84.

95. Singh, V.; Gu, N.; Wang, X. A theoretical framework of a BIM-based multi-disciplinary collaboration platform. Autom. Constr. 2011, 20, 134-144. [CrossRef]

96. Liu, Y.; van Nederveen, S.; Hertogh, M. Understanding effects of BIM on collaborative design and construction: An empirical study in China. Int. J. Proj. Manag. 2017, 35, 686-698. [CrossRef]

97. Edirisinghe, R.; London, K.A.; Kalutara, P.; Aranda-Mena, G. Building information modelling for facility management: Are we there yet? Eng. Constr. Archit. Manag. 2017, 24, 1119-1154. [CrossRef]

98. Xu, Y.Q.; Kong, Y.Y. Analysis of the influence factors of application and promotion of BIM in China. J. Eng. Manag. 2016, 30, 28-32.

99. Khosrowshahi, F.; Arayici, Y. Roadmap for implementation of BIM in the UK construction industry. Eng. Constr. Archit. Manag. 2012, 19, 610-635. [CrossRef]

100. Chien, K.-F.; Wu, Z.-H.; Huang, S.-C. Identifying and assessing critical risk factors for BIM projects: Empirical study. Autom. Constr. 2014, 45, 1-15. [CrossRef] 
101. Xu, H.; Feng, J.; Li, S. Users-orientated evaluation of building information model in the Chinese construction industry. Autom. Constr. 2014, 39, 32-46. [CrossRef]

102. Zhang, X.; Azhar, S.; Nadeem, A.; Khalfan, M. Using Building Information Modelling to achieve Lean principles by improving efficiency of work teams. Int. J. Constr. Manag. 2018, 18, 293-300. [CrossRef]

103. Nawi, M.N.M.; Haron, A.T.; Hamid, Z.A.; Kamar, K.A.M.; Baharuddin, Y. Improving integrated practice through building information modeling-integrated project delivery (BIM-IPD) for Malaysian industrialised building system (IBS) Construction Projects. Malays. Constr. Res. J. 2014, 15, 1-15.

104. Yaakob, M.; Wan, W.N.A.; Radzuan, K. Critical success factors to implementing building information modeling in Malaysia construction industry. Int. Rev. Manag. Mark. 2016, 6, 252-256.

105. Aranda-Mena, G.; Crawford, J.; Chevez, A.; Froese, T. Building information modelling demystified: Does it make business sense to adopt BIM? Int. J. Manag. Proj. Bus. 2009, 2, 419-434. [CrossRef]

106. Enshassi, A.; AbuHamra, L.; Mohamed, S. Barriers to implementation of building information modelling (BIM) in the palestinian construction industry. Int. J. Constr. Proj. Manag. 2016, 8, 103.

107. Eadie, R.; Odeyinka, H.; Browne, M.; McKeown, C.; Yohanis, M. Building information modelling adoption: An analysis of the barriers to implementation. J. Eng. Archit. 2014, 2, 77-101.

108. Ott, R.L.; Longnecker, M.T. An Introduction to Statistical Methods and Data Analysis; Cengage Learning: Boston, MA, USA, 2015.

109. Ling, F.Y.Y.; Low, S.P.; Wang, S.Q.; Lim, H.H. Key project management practices affecting Singaporean firms' project performance in China. Int. J. Proj. Manag. 2009, 27, 59-71. [CrossRef]

110. Flick, U. The Sage Qualitative Research Kit: Collection; SAGE Publications Limited: London, UK, 2009.

111. Pallant, J.; Manual, S.S. A step by step guide to data analysis using SPSS for windows. In SPSS Survival Manual; Open University Press: New York, NY, USA, 2007.

112. Lam, P.T.I.; Chan, E.H.W.; Ann, T.W.; Cam, W.C.N.; Jack, S.Y. Applicability of clean development mechanism to the Hong Kong building sector. J. Clean. Prod. 2015, 109, 271-283. [CrossRef]

113. Field, A.P. K endall's Coefficient of Concordance. Wiley StatsRef Stat. Ref. Online 2014. [CrossRef]

114. Chan, D.W.M.; Choi, T.N.Y. Difficulties in executing the Mandatory Building Inspection Scheme (MBIS) for existing private buildings in Hong Kong. Habitat Int. 2015, 48, 97-105. [CrossRef]

115. Daniel, W.M.; Hung, H.T.W. An empirical survey of the perceived benefits of implementing the Mandatory Building Inspection Scheme (MBIS) in Hong Kong. Facilities 2015, 33, 337-366.

116. Hartmann, A.; Love, P.E.D.; Hon, C.K.H.; Chan, A.P.C.; Chan, D.W.M. Strategies for improving safety performance of repair, maintenance, minor alteration and addition (RMAA) works. Facilities 2011, 29, 591-610.

117. Chen, P.Y.; Smithson, M.; Popovich, P.M. Correlation: Parametric and Nonparametric Measures; SAGE: London, UK, 2002.

118. Lewin, A.; Silver, C. Using Software in Qualitative Research; SAGE: London, UK, 2014.

119. Bazeley, P.; Jackson, K. Qualitative Data Analysis with NVivo; SAGE Publications Limited: London, UK, 2013.

120. Field, A. Discovering Statistics Using IBM SPSS Statistics; SAGE: London, UK, 2013.

121. Farooq, U.; Rehman, S.K.U.; Javed, M.F.; Jameel, M.; Aslam, F.; Alyousef, R. Investigating BIM Implementation Barriers and Issues in Pakistan Using ISM Approach. Appl. Sci. 2020, 10, 7250. [CrossRef] 